UDC 66.097.3:541.64.66(0765)

\author{
E.S. Mammadova ${ }^{a}$, Z.Ch. Salaeva ${ }^{a}$, A.E. Huseinova ${ }^{b}$, G.A. Mammadaliev ${ }^{a}$
}

\title{
SYNTHESIS AND APPLICATION OF ALKYLPHENOLS OBTAINED BY ALKYLATION OF PHENOL WITH $\mathrm{C}_{8}-\mathrm{C}_{10} \propto$-OLEFINS
}

\author{
${ }^{a}$ Open-Joint-Stock Company «Olefins Scientific-Research and Production Center», Baku, Azerbaijan \\ b Sumgait State University, Sumgait, Azerbaijan
}

\begin{abstract}
The paper reports the results of experiments on the development of production of alkylphenols using the method of thermal alkylation of phenol with $\alpha$-olefins. The influence of technological parameters, such as temperature, pressure, reaction time and molar ratio of reagents, was studied. An increase in the reaction temperature and molar ratio of phenol:olefin positively affects the degree of conversion of olefins, which reaches a maximum value of $85 \%$ at $425^{\circ} \mathrm{C}$ and molar ratio of fenol:olefin of 5:1. However, an increase in the reaction temperature higher than $400^{\circ} \mathrm{C}$ negatively affects the selectivity of the process for «extremely substituted» alkylphenols, which decreases from $97 \%$ to $76 \%$ at $400^{\circ} \mathrm{C}$ and $425^{\circ} \mathrm{C}$, respectively. The optimum conditions of the process were found as follows: the reaction temperature of $400^{\circ} \mathrm{C}$, the pressure of $6.0 \mathrm{MPa}$, the molar ratio of phenol:olefins $=4: 1$ and the reaction time of $1 \mathrm{~h}$. Under these conditions, the degree of conversion of olefins and the selectivity with respect to monoalkyphenol are equal to $50 \%$ and $90 \%$, respectively. The possibility of full isomerization of alkylphenols ethers into relevant alkylfenols on the catalyst KU-2 was shown. Prepared alkylphenols were tested as a basis for the production of surfactants. Thermal alkylphenols were compared with acidic samples of alkylphenols. It was shown that alkylphenols prepared by thermal alkylation process allow producing surfactants, which exhibit high surface-active properties with reference to the interfacial tension of solutions «surfactants-kerosene». Based on the obtained results, the flowsheet of the thermal alkylation process of phenol with $\alpha$-olefins was proposed.
\end{abstract}

Keywords: alkylation, alkylphenols, $\alpha$-olefins, isomerization, optimal conditions, manufacturing scheme, process.

DOI: $10.32434 / 0321-4095-2020-130-3-116-121$

\section{Introduction}

Synthetic alkylphenols are important semiproducts in petrochemical industry and industrial organic synthesis. Their main bulk is consumed in the synthesis of nonionic surfactants. The use of alkylphenylpolyglycolic ethers in oil industry is a largetonnage production for oil recovery enhancement through its flooding. Although oxyethylated normal alcohols are used for the same purposes, the cost and simplicity of production of alkylphenylpolyglycolic ethers as well as the availability of raw material represent great advantages over alcohols.

Alkylphenols are widely used in the production of oil-soluble polymers for paint-and-varnish industry. As bactericide and disinfecting agents, alkylphenols sufficiently surpass phenols, cresols, and so on. Alkylphenols are also used as antioxidant additives to polymers and lubricating oils [1-4].

As it is known, the catalysts used for alkylation of phenol with olefins are mineral and organic acids, haloids of metals, amorphous and crystalline alumosilicates, different phenolates, and sulfocationites (KU-2) [5]. Although alkylphenols can be obtained using some of these catalysts to obtain targeted ortho-isomer, the formation of phenol-containing wastewaters make these processes undesirable for application. Other catalysts, alumisilicates, zeolites and KU-2, do not exhibit sufficient selective action towards the formation of ortho-isomer and lose their catalytic activity after some time [6,7]. Moreover, when using some catalysts together with monoalkylphenol, the polyalkylphenols, which have not been widely used,

(C) E.S. Mammadova, Z.Ch. Salaeva, A.E. Huseinova, G.A. Mammadaliev, 2020 
are formed in small quantities.

This paper deals with the development of thermal alkylation process of phenol with linear $\alpha$-olefin fraction $\mathrm{C}_{8}-\mathrm{C}_{10}$. The reaction proceeds according to the following scheme:

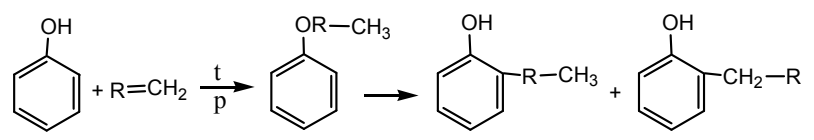

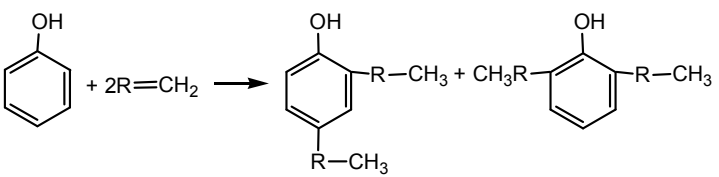

\section{Experimental, results and discussion}

Phenol (GOST 236-68, premium grade) and $\alpha$-olefins $\mathrm{C}_{8}-\mathrm{C}_{10}$ produced by high-temperature oligomerization of ethylene in the presence of organometallic catalyst [8-10] were used as raw materials.

Alkylation process was investigated by means of continuously operating installation (Fig. 1).

Phenols and olefins in a given molar ratio were heated up to $220^{\circ} \mathrm{C}$ in a heater (3) and passed to a hollow reactor (4), where the necessary reaction temperature and pressure were maintained. After that, the reaction products were supplied to a separator (5) and further to the system of rectification columns $(6,7,8)$.

The reaction products were analyzed using an LKhM-8MD chromatograph (model 5) equipped with a flame ionization detector (carrier-gas was helium, carrier-gas velocity was $40 \mathrm{~mL} / \mathrm{min}$ and column temperature was $50-100^{\circ} \mathrm{C}$ ). Cellite 545 with a stationary phase benton $34+$ didecyl phthalate (1:1) was used as a sorbent.

To determine the optimum ratio of phenol:olefin, a number of experiments were carried out at different temperatures and the results are shown in Fig. 2.

The highest conversion ( $85 \mathrm{wt} . \%$ ) was observed at $425^{\circ} \mathrm{C}$ and molar ratio of $5: 1$.

However, an increase in the reaction temperature higher than $400^{\circ} \mathrm{C}$ negatively affects the selectivity of the process for «extremely substituted» alkylphenols, which decreases from $97 \%$ (at $400^{\circ} \mathrm{C}$ ) to $76 \%$ (at $425^{\circ} \mathrm{C}$ ) (Fig. 3).

The formation of considerable quantities of lowmolecular alkylphenols is also observed, which causes the destruction of olefins under such conditions.

Pressure is an important factor in thermal alkylation of phenol. Figure 4 shows the effect of pressure on the alkylation at different reaction duration.

To achieve a maximum conversion of olefins at sufficiently high selectivity towards «extremely substituted» alkylphenols, the pressure of 50-70 atm must be kept in the system at the reaction time of $60 \mathrm{~min}$. A further increase in the reaction time causes an increase in the content of isomers with «internal» substitution in alkylates.

Summarizing the obtained data, it must be noted that the reaction of thermal alkylation of phenol with $\alpha$-olefins proceeds in the range of critical temperatures and pressures for phenol $\left(\mathrm{T}_{\mathrm{cr}}=419^{\circ} \mathrm{C}\right.$ and $\left.\mathrm{P}_{\mathrm{cr}}=60 \mathrm{~atm}\right)$. In compliance with the conditions of the reaction, the selectivity with respect to «extremely substituted» alkylphenols reaches about 93-95\%.

Based on the experimental data (Table 1), the optimum conditions of alkylation process were determined as follows: temperature of about $400^{\circ} \mathrm{C}$,

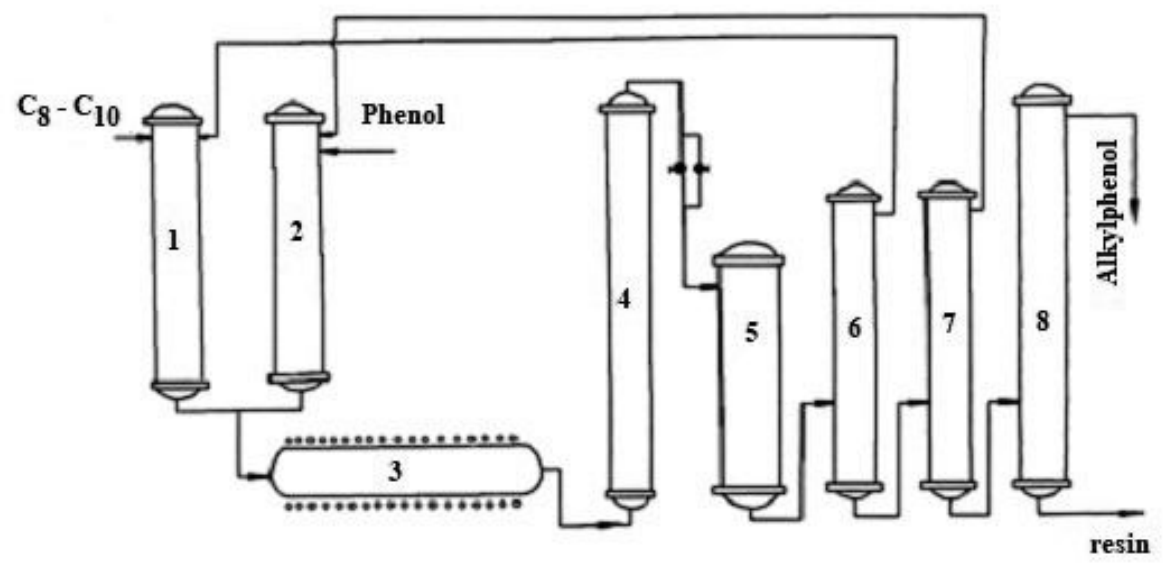

Fig. 1. Installation diagram: 1 - olefin measurer; 2 - phenol measurer; 3 - heater; 4 - reactor; 5 - separator; $6,7,8-$ rectification columns

Synthesis and application of alkylphenols obtained by alkylation of phenol with $\mathrm{C}_{8}-\mathrm{C}_{10} \alpha$-olefins 


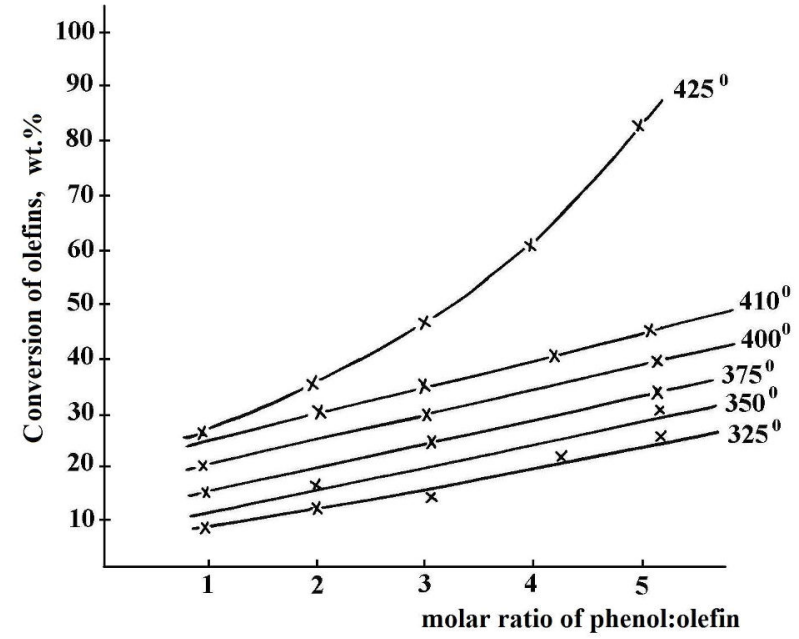

Fig. 2. Conversion of olefins as a function of molar phenol:olefin ratio at different temperatures for alkylation of phenol with olefins

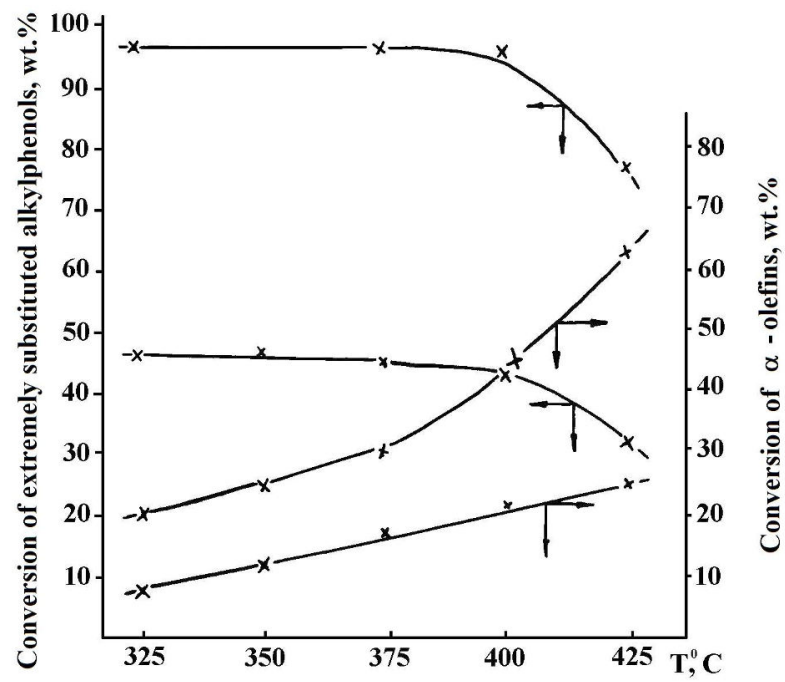

Fig. 3. Effects of temperature on the conversion of «extremely substituted» alkylphenols and the conversion of $\alpha$-olefins at a molar ratio of phenol:olefin $=5: 1$

pressure of 60 atm, molar ratio of phenols:olefins $=4: 1$, reaction time of $1 \mathrm{~h}$ and density of reaction mixture $0.28-0.3 \mathrm{~g} / \mathrm{cm}^{3}$. The bestachieved results are as follows: the conversion of olefins equals to about $50 \%$, the selectivity with respect to monoalkylphenol is $90-96 \%$ and their yield is $45 \%$.

We also observed the formation of alkylphenols ethers which can be easily isomerized (for $90 \%$ ) into relevant alkylphenols on the catalyst KU-2 at $60^{\circ} \mathrm{C}$.

The life time of the catalyst KU-2 under these conditions is not less than 1000 hours, but the spent

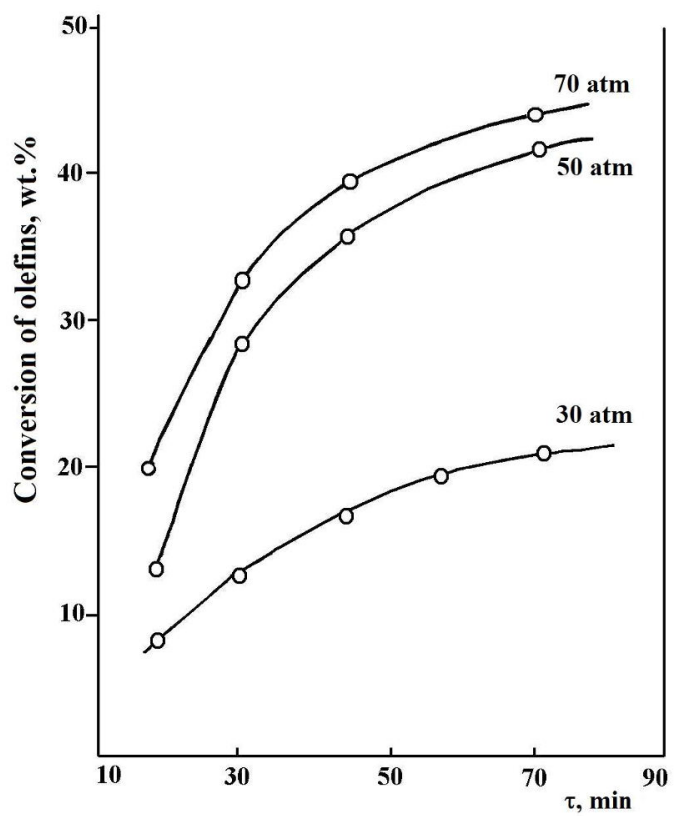

Fig. 4. The influence of pressure on the conversion of olefins

catalyst cannot be regenerated.

It is well known that one of the main directions of application of these alkylphenols is the production of surfactants. In case of the synthesis of surfactant based on alkylphenols, it was determined that the degree of its biodegradation is closely connected with the structure of alkylphenols in its composition. Lowsoluble surfactants are obtained based on orthosecondary alkylphenols, whereas water-soluble surfactants are obtained using highly-branched paraalkylphenols. It was also found that surfactants based on alkylaromatic compounds with linear structure, unlike their branched isomers, are characterized by high biodegradability $[6-7,11]$.

The targeted fractions of alkylphenols were separated from the synthesized products as an initial raw material for the production of nonionic surfactants. Table 2 shows the results of comparative tests of the use of thermal alkylphenol and acidic samples of alkylphenols in the production of nonionic surfactants. One can see that nonionic surfactants which exhibit high surface-active properties with respect to the interfacial tension of solutions surfactants-kerosene can be produced based on alkylphenols and using thermal alkylation.

\section{Conclusions}

We developed the process of the synthesis of alkylphenols by alkylation of phenol with $\mathrm{C}_{8}-\mathrm{C}_{10}$ $\alpha$-olefins and selected the optimal synthesis conditions as follows: the temperature of $400^{\circ} \mathrm{C}$, the pressure of $60 \mathrm{~atm}$, the phenol:olefin molar ratio of $4: 1$, and the reaction time of $1 \mathrm{~h}$. Under these 
Table 1

Results of thermal alkylation of phenol with $\alpha$-olefins $C_{8}-C_{10}$ by using a flow-type installation (the reaction time was $1 \mathrm{~h}$ )

\begin{tabular}{|c|c|c|c|c|c|c|c|c|}
\hline \multicolumn{4}{|c|}{ Conditions of experiments } & \multirow{2}{*}{$\begin{array}{l}\text { Conversion } \\
\text { of olefins, \% }\end{array}$} & \multirow{2}{*}{$\begin{array}{c}\text { Selectivity with respect to } \\
\text { monoalkyl-phenol, } \%\end{array}$} & \multirow{2}{*}{$\begin{array}{c}\text { Yield of } \\
\text { monoalkylphenols, \% }\end{array}$} & \multirow{2}{*}{$\begin{array}{c}\text { Total yield of } \\
\text { alkylphenols, \% }\end{array}$} & \multirow{2}{*}{$\begin{array}{l}\text { Total yield of } \\
\text { ethers, } \%\end{array}$} \\
\hline $\mathrm{T}^{0} \mathrm{C}$ & $\begin{array}{c}\text { Pressure, } \\
\text { atm }\end{array}$ & Phenol:olefin & $\begin{array}{l}\text { Density, } \\
\mathrm{g} / \mathrm{cm}^{3}\end{array}$ & & & & & \\
\hline $\begin{array}{l}375 \\
375 \\
375 \\
375\end{array}$ & 30 & $1: 1$ & & 7.2 & 93.4 & 5.8 & 5.9 & 0.30 \\
\hline 400 & 30 & $2: 1$ & \multirow{6}{*}{0.35} & 13.5 & 91.2 & 12.3 & 12.65 & 0.85 \\
\hline 400 & 40 & 3:1 & & 18.6 & 94.8 & 17.6 & 18.10 & 0.50 \\
\hline 400 & 50 & $4: 1$ & & 42.5 & 96.7 & 41.1 & 41.65 & 0.85 \\
\hline 400 & 60 & $2: 1$ & & 14.3 & 92.4 & 13.2 & 13.50 & 0.80 \\
\hline 400 & 50 & $3: 1$ & & 32.5 & 95.4 & 31.0 & 31.42 & 1.08 \\
\hline 400 & 60 & $4: 1$ & & 46.7 & 95.8 & 44.8 & 45.80 & 0.90 \\
\hline 410 & 30 & $2: 1$ & \multirow{6}{*}{0.35} & 15.7 & 89.5 & 14.0 & 14.65 & 1.05 \\
\hline 410 & 40 & $3: 1$ & & 34.8 & 92.1 & 32.1 & 33.10 & 1.70 \\
\hline 410 & 50 & $4: 1$ & & 43.5 & 93.8 & 40.8 & 41.90 & 1.60 \\
\hline 410 & 60 & $3: 1$ & & 25.8 & 90.5 & 23.4 & 24.30 & 1.50 \\
\hline 410 & 60 & $4: 1$ & & 49.9 & 95.6 & 47.8 & 48.70 & 1.20 \\
\hline 410 & 50 & $3: 1$ & & 38.7 & 96.4 & 37.3 & 38.00 & 0.70 \\
\hline 420 & 30 & $4: 1$ & \multirow{5}{*}{0.30} & 50.2 & 91.2 & 45.8 & 46.80 & 3.40 \\
\hline 420 & 40 & $3: 1$ & & 39.5 & 90.2 & 35.7 & 36.70 & 2.80 \\
\hline 420 & 50 & $3: 1$ & & 42.4 & 88.3 & 37.4 & 38.80 & 3.60 \\
\hline 420 & 60 & $3: 1$ & & 44.5 & 83.5 & 39.9 & 41.20 & 3.30 \\
\hline 420 & 50 & $3: 1$ & & 44.7 & 88.6 & 39.7 & 41.20 & 3.50 \\
\hline
\end{tabular}

Characteristics of oxyethylated alkylphenols prepared by different methods

Table 2

\begin{tabular}{|c|c|c|c|c|c|c|c|}
\hline \multirow[b]{2}{*}{$\begin{array}{c}\text { Name of alkylphenols based } \\
\text { on } \alpha \text {-olefins } C_{8}-C_{10}\end{array}$} & \multirow[b]{2}{*}{$\begin{array}{c}\text { Molar mass of } \\
\text { alkylphenols } \\
\text { (calculated by } \\
\text { hydroxyl number of } \\
\text { alkylphenol) }\end{array}$} & \multirow[b]{2}{*}{$\begin{array}{c}\text { Number of } \\
\text { connected } \\
\text { moles of } \\
\text { ethylene } \\
\text { oxide }\end{array}$} & \multicolumn{5}{|c|}{ Characteristics of oxyethylates } \\
\hline & & & $\begin{array}{c}\text { Content of } \\
\text { oxyethylene, } \\
\text { wt. } \%\end{array}$ & $\begin{array}{c}\text { Content of } \\
\text { polyethylene } \\
\text { glycol, wt.\% }\end{array}$ & $\begin{array}{l}\text { Freezing } \\
\text { point, }{ }^{0} \mathrm{C}\end{array}$ & $\begin{array}{c}\text { Cloud point } \\
\text { of } 1 \% \\
\text { surfactant, } \\
\text { wt. } \%\end{array}$ & $\begin{array}{c}\text { Interfacial } \\
\text { tension on } \\
\text { kerosene } \\
0,05 \% \\
\text { surfactant }\end{array}$ \\
\hline $\begin{array}{l}\text { Alkylphenols of thermal } \\
\text { alkylation }\end{array}$ & 238 & $\begin{array}{l}11.8 \\
15.3\end{array}$ & $\begin{array}{l}68.0 \\
73.7\end{array}$ & $\begin{array}{l}4.3 \\
5.2\end{array}$ & $\begin{array}{l}19,3 \\
20,5\end{array}$ & $\begin{array}{c}68-69 \\
90-90.5\end{array}$ & $\begin{array}{l}4.60 \\
5.10\end{array}$ \\
\hline $\begin{array}{l}\text { Alkylphenols obtained by } \\
\text { catalytic alkylation on KU-2 }\end{array}$ & 224 & $\begin{array}{l}12.1 \\
15.0 \\
\end{array}$ & $\begin{array}{l}70.8 \\
74.9 \\
\end{array}$ & $\begin{array}{l}3.8 \\
4.2 \\
\end{array}$ & $\overline{2}-\overline{5}$ & $\begin{array}{l}68-71 \\
89-92 \\
\end{array}$ & $\begin{array}{l}3.96 \\
4.14\end{array}$ \\
\hline
\end{tabular}

conditions the olefin conversion reaches $50 \%$, the selectivity towards monoalkylphenol is $90-96 \%$ and their yield is $45-46 \%$. It should be noted that the obtained alkylphenols mainly consist of ortho-isomers (about 70\%) which are highly biodegradable. The main advantages of thermal alkylation over the catalytic one are as follows: a high selectivity of the process, the lack of reaction by-products, the simplicity of technological design and the absence of an expensive catalyst KU-2.

The flowsheet of the synthesis of alkylphenols was developed by using thermal alkylation of phenol with $\alpha$-olefins. The process includes the following stages: thermal alkylation of phenol, throttling the reaction mixture, isolation of alkylphenols and catalytic isomerization of ether and alkylphenols.

\section{REFERENCES}

1. Alkylation of phenol with olefins and alcohols in the presence of glycol sulfate ester / Goncharenko N.A., Fedotov A.S., Dubinin A.V., Vorobyeva K.Y. // Vestnik of the Orenburg State University. - 2003. - P.139-140.

2. Alkylation of benzene with higher olefins on heterogeneous catalysts / Borutskii P.N., Kozlova E.G., Podkletnova N.M., Gil'chenok N.D., Sokolov B.G., Zuev V.A., Shatovkin A.A. // Pet. Chem. - 2007. - Vol.47. - P.250-261.

3. Cherezova E.N., Nugumanova G.N., Shaliminova D.P. Alkylation of phenol with olefins as a synthesis method of stabilizers for polymers. - Kazan: KNITU Publishers, 2013. - 80 p.

4. New demulsifiers for petroleum preparation processes / Koshelev V.N., Klimova L.Z., Starikov V.V., Nizova S.A. // Chem. Technol. Fuels Oils. - 2000. - Vol.36. - P.97-100. 
5. The method of producing alkyl phenols / Belov P.S., Korenev K.D., Tsvetkov O.N., Grigoryeva E.N. // Author's certificate USSR. - No. 709611. - 1980.

6. A catalyst for the alkylation of phenol by olefins / Bakhshi-zadeh A.A., Spivak R.E., Melikova Z.M., Gamidzadeh E.G., Ovanesova G.S., Markaryan N.S.C.A. // Author's certificate USSR. - No. 727216. - 1980.

7. The method of producing alkyl phenols / Trubnikov A.G., Zavorotniy V.A., Shalsirov S.K. Kapustin P.P., Qritsenko A.A., Rumantsev Y.A. Khallilulin V.H., Belov P.S., Korenev K.D. // Patent RU. - No. 1703637. - 1992.

8. Mammadaliev H.A. Application and production of $\alpha$-olefins obtained by oligomerization of ethylene // Voprosy Khimii i Kimicheskoi Tekhnologii. - 2006. - No. 2. - P.57-61.

9. Mammadaliev H.A. Synthesis of higher $\alpha$-olefins by ethylene oligomerization on nickel-complex catalytic systems // Voprosy Khimii i Kimicheskoi Tekhnologii. - 2010. - No. 1. P.23-31.

10. Production of higher olefins by oligomerization of propylene / Salaeva Z.C., Seidov N.M., Mammadaliev H.A., Mammadova E.S. // Voprosy Khimii i Kimicheskoi Tekhnologii. - 2014. - No. 1. - P.35-38.

11. Chernishov D.A., NesterovaT.N. Alkylation of phenol with nonene-1 from the viewpoint of industrial realities // Proceedings of Samara Scientific Center of the Russian Academy of Sciences. - 2011. - Vol.13. - No. 4(4). - P.1172-1177.

Received 16.09.2019

\section{СИНТЕЗ І ВИКОРИСТАННЯ АЛКІЛФЕНОЛІВ, ОДЕРЖАНИХ АЛКІЛУВАННЯМ ФЕНОЛУ $\mathrm{C}_{8}-\mathrm{C}_{10}$ }

\section{Е.С. Маммадова, З.Ч. Салаєва, А.Е. Гусейнова, \\ Г.А. Маммадалієв}

У статті викладені результати досліджень стосовно розробки виробництва алкілфенолів з використанням методу термічного алкілування фенолу $\alpha$-олефінами. Вивчено вплив технологічних параметрів, таких як температура, тиск, тривалість реакції і молярне співвідношення реагентів. Зростання температури і молярного співвідношення фенол:олефін позитивно впливає на ступінь конверсії олефінів, що досягає максимального значення $85 \%$ при $425^{\circ} \mathrm{C}$ і молярному співвідношенні фенол:олефін, рівному 5:1. Однак, збільшення реакційної температури вище, ніж $400^{\circ} \mathrm{C}$ негативно відбивається на селективності процесу для «екстремально заміщених» алкілфенолів, яка знижується від $97 \%$ до $76 \%$ при $400^{\circ} \mathrm{C}$ i $425^{\circ} \mathrm{C}$, відповідно. Визначені наступні оптимальні умови проиесу: реакиійна температура $400^{\circ} \mathrm{C}$, тиск $6 \mathrm{MPa,} \mathrm{молярне} \mathrm{співвідношення} \mathrm{фенол:-}$ олефін=4:1 та тривалість реакції 1 год. За таких умов ступінь конверсії олефінів та селективність стосовно моноалкілфенолу становлять 50\% та 90\%, відповідно. Показана можлливість повної ізомеризації алкілфенольних етерів у відповідні алкілфеноли на каталізаторі KU-2. Виготовлені алкілфеноли були протестовані як основа для виробництва поверхнево-активних речовин. Термічні алкілфеноли були порівняні з кислими зразками алкілфенолів. Показано, що алкілфеноли, виготовлені шляхом процесу термічного алкілування, дозволяють отримувати іонногенні поверхнево-активні речовини, що проявляють вищу поверхневу активність стосовно міжфазного натягу розчинів «поверхнево-активна речовина - гас». На основі отриманих результатів розроблена технологічна схема процесу термічного алкілування фенолу $\alpha$-олефінами.

Ключові слова: алкілування; алкілфеноли; $\alpha$-олефіни; ізомеризація; оптимальні умови; технологічна схема; процес.

\section{SYNTHESIS AND APPLICATION OF ALKYLPHENOLS OBTAINED BY ALKYLATION OF PHENOL WITH $\mathrm{C}_{8}-\mathrm{C}_{10}$ $\alpha$-OLEFINS}

\author{
E.S. Mammadova ${ }^{a}$, Z.Ch. Salaeva ${ }^{a,}{ }^{*}$, A.E. Huseinova ${ }^{b}$, \\ G.A. Mammadaliev ${ }^{a}$
}

a Open-Joint-Stock Company «Olefins Scientific-Research and Production Center», Baku, Azerbaijan

\section{b Sumgait State University, Sumgait, Azerbaijan \\ * e-mail: olefin-merkez@mail.ru}

The paper reports the results of experiments on the development of production of alkylphenols using the method of thermal alkylation of phenol with $\alpha$-olefins. The influence of technological parameters, such as temperature, pressure, reaction time and molar ratio of reagents, was studied. An increase in the reaction temperature and molar ratio of phenol:olefin positively affects the degree of conversion of olefins, which reaches a maximum value of $85 \%$ at $425^{\circ} \mathrm{C}$ and molar ratio of fenol:olefin of 5:1. However, an increase in the reaction temperature higher than $400^{\circ} \mathrm{C}$ negatively affects the selectivity of the process for «extremely substituted» alkylphenols, which decreases from $97 \%$ to $76 \%$ at $400^{\circ} \mathrm{C}$ and $425^{\circ} \mathrm{C}$, respectively. The optimum conditions of the process were found as follows: the reaction temperature of $400^{\circ} \mathrm{C}$, the pressure of $6.0 \mathrm{MPa}$, the molar ratio of phenol:olefins $=4: 1$ and the reaction time of $1 \mathrm{~h}$. Under these conditions, the degree of conversion of olefins and the selectivity with respect to monoalkyphenol are equal to $50 \%$ and $90 \%$, respectively. The possibility of full isomerization of alkylphenols ethers into relevant alkylfenols on the catalyst $K U-2$ was shown. Prepared alkylphenols were tested as a basis for the production of surfactants. Thermal alkylphenols were compared with acidic samples of alkylphenols. It was shown that alkylphenols prepared by thermal alkylation process allow producing surfactants, which exhibit high surface-active properties with reference to the interfacial tension of solutions «surfactants-kerosene». Based on the obtained results, the flowsheet of the thermal alkylation process of phenol with $\alpha$-olefins was proposed.

Keywords: alkylation; alkylphenols; $\alpha$-olefins; isomerization; optimal conditions; manufacturing scheme; process.

\section{REFERENCES}

1. Goncharenko N.A., Fedotov A.S., Dubinin A.V., Vorobyeva K.Y. Alkylation of phenol with olefins and alcohols in the presence of glycol sulfate ester. Vestnik of the Orenburg State University, 2003, pp. 139-140.

2. Borutskii P.N., Kozlova E.G., Podkletnova N.M., Gil'chenok N.D., Sokolov B.G., Zuev V.A., Shatovkin A.A. Alkylation of benzene with higher olefins on heterogeneous catalysts. Petroleum Chemistry, 2007, vol. 47, pp. 250-261.

3. Cherezova E.N., Nugumanova G.N., Shaliminova D.P., Alkylation of phenol with olefins as a synthesis method of stabilizers for polymers. KNITU Publishers, Kazan, 2013. 80 p.

4. Koshelev V.N., Klimova L.Z., Starikov V.V., Nizova S.A. New demulsifiers for petroleum preparation processes. Chemistry and Technology of Fuels and Oils, 2000, vol. 36, pp. 97-100. 
5. Belov P.S., Korenev K.D., Tsvetkov O.N., Grigoryeva E.N., The method of producing alkyl phenols. Author's certificate USSR, no. 709611, 1980.

6. Bakhshi-zadeh A.A., Spivak R.E., Melikova Z.M., Gamid-zadeh E.G., Ovanesova G.S., Markaryan N.S.C.A., A catalyst for the alkylation of phenol by olefins. Author's certificate USSR, 727216, 1980.

7. Trubnikov A.G., Zavorotniy V.A., Shalsirov S.K. Kapustin P.P., Qritsenko A.A., Rumantsev Y.A. Khallilulin V.H., Belov P.S., Korenev K.D., The method of producing alkyl phenols. Patent RU, no. 1703637, 1992.

8. Mammadaliev H.A. Application and production of $\alpha$-olefins obtained by oligomerization of ethylene. Voprosy Khimii i Kimicheskoi Tekhnologii, 2006, no. 2, pp. 57-61.

9. Mammadaliev H.A. Synthesis of higher $\alpha$-olefins by ethylene oligomerization on nickel-complex catalytic systems. Voprosy Khimii i Kimicheskoi Tekhnologii, 2010, no. 1, pp. 23-31.

10. Salaeva Z.C., Seidov N.M., Mammadaliev H.A., Mammadova E.S. Production of higher olefins by oligomerization of propylene. Voprosy Khimii i Kimicheskoi Tekhnologii, 2014, no. 1, pp. 35-38.

11. Chernishov D.A., Nesterova T.N. Alkylation of phenol with nonene-1 from the viewpoint of industrial realities. Proceedings of Samara Scientific Center of the Russian Academy of Sciences, 2011, vol. 13, no. 4(4), pp. 1172-1177. 